\title{
MIĘDZYNARODOWA PRACA SOCJALNA WOBEC PROCESU WYKLUCZENIA SPOŁECZNEGO I INKLUZJI
}

\begin{abstract}
Processes of exclusion and inclusion in context of international social work

Cooperation and exchange of practical experiences at the field of international social work becomes not only an element of the development of theory and practice of social work against exclusion, but also an element of the policy of integration and cohesion, as well as programs of inclusion in many countries. Reflecting processes of exclusion in interdisciplinary context, there are undertaken different activities base on sociological theories, theories of social work and important normative procedures for new democracy. The presented paper analyses social exclusion and inclusion in sociological prospective, theories and practices for different groups of excluded, and issues related to international social work focused on problems of migration.
\end{abstract}

Key words: social exclusion, inclusion, migrations, international social work

\section{Wprowadzenie}

Na płaszczyźnie międzynarodowej pracy socjalnej istnieje wiele idei, teorii oraz strategii, które wyjaśniają mechanizmy wykluczania i ukierunkowują procesy inkluzji. Po dwóch dekadach wdrażania europejskiej polityki spójności możemy też odnaleźć przykłady propozycji programów wsparcia i pracy socjalnej z osobami oraz grupami marginalizowanymi w różnych krajach, które warto by było upowszechniać. Pojawiają się także nowe wyzwania w kontekście procesów wykluczenia społecznego oraz podejmowania działań wspierająco-integrujących wobec wykluczanych, ponieważ obok klasycznych przyczyn wykluczenia związanych z ubóstwem, bezrobociem, niepełnosprawnością są te związane $\mathrm{z}$ migracjami i uchodźctwem. Wymagają one podejmowania teoretycznie uzasadnionych i empirycznie zweryfikowanych działań inkluzyjnych oraz rozwiązań legislacyjnych, które umożliwią ich wdrażanie.

Współcześnie istnieje też konieczność przygotowania profesjonalistów społecznych, podejmujących działania w zakresie międzynarodowej pracy socjalnej, oraz potrzeba kształtowania nowej świadomości społecznej wobec osób narażonych na wykluczenie, 
a szczególnie wobec migrantów. By temu sprostać, warto podejmować refleksję nad złożonością procesów wykluczenia i inkluzji oraz promować międzynarodowe inicjatywy na rzecz wykluczanych.

\section{Społeczne wykluczenie i proces inkluzji w perspektywie socjologicznej}

Pojęcie społecznego wykluczenia pojawiło się w „zastępstwie” pojęcia ubóstwa z początkiem lat dziewięćdziesiątych XX wieku jako relatywny sposób konceptualizacji wielu namacalnych problemów społecznych związanych z przeobrażeniami społeczno-politycznymi, wynikającymi także z ogólnoeuropejskich przemian, ruchów solidarnościowych oraz wizji społecznej integracji w unifikującej się Europie (por. Sałustowicz 2003: 199). Natomiast w ostatnich dwóch dekadach społeczne wykluczenie (social exclusion) stało się stałym elementem publicznego dialogu i swoistym słowem kluczem używanym nie tylko w akademickich dyskusjach, lecz także, a może przede wszystkim, w języku praktyków zabiegających o sfinansowanie różnych programów socjalnych służących społecznej reintegracji ludzi wykluczonych (Frieske 2004: 14).

W literaturze przedmiotu badań i dokumentach publicznych pojawiło się wiele ujęć i interpretacji tego procesu, a kwestia wykluczenia społecznego była wyjaśniana w perspektywie różnych teorii socjologicznych, między innymi teorii nierówności społecznych czy też teorii stratyfikacji społecznej Maxa Webera, teorii rozwarstwienia społecznego Kingsleya Daviesa i Wilberta E. Moore’a, teorii zdolności capability Amartyi Sena.

M. Weber ukazał wielowymiarowość zróżnicowania społecznego, które przejawia się i powstaje na poziomie gospodarki, systemu społecznego, politycznego i rynku. Ta „wielowymiarowość" zróżnicowania i nierówności społecznych jest spowodowana przez czynniki: ekonomiczne, takie jak dochód czy bogactwo, społeczne - określane przez prestiż i szacunek, polityczne - przez na przykład władzę. Według tej teorii struktura jest konsekwencją stosunku do produkcji i nabywania dóbr, stany są zaś następstwem pewnych wzorów konsumpcji dóbr manifestujących się także poprzez styl życia (Domański 2004: 37-41).

Funkcjonalna teoria rozwarstwienia sformułowana przez K. Davisa i W.E. Moore’a oparta jest na założeniu, że nie ma społeczeństwa nieuwarstwionego i owo uwarstwienie wyjaśnia powszechną konieczność rozwarstwienia każdego systemu społecznego. Rozwarstwienie rozumiane jest tutaj jako nierówny podział korzyści materialnych i prestiżu społecznego, a społeczeństwo traktowane jest jako system społeczny. Społeczeństwo, aby poprawnie funkcjonować, musi w pewien określony sposób przydzielać swym członkom pozycje społeczne i skłaniać ich do wykonywania związanych z tymi pozycjami obowiązków (Szacka 2003: 357).

W teorii sprawiedliwości - mającej za podstawę koncepcję zdolności A. Sena przyjmuje się, że ludzie są równi w zakresie potrzeb, w rzeczywistości, jednak ludzie mają różne potrzeby, w zależności od ich stanu zdrowia, wieku czy wykonywanej pracy. 
W obliczu różnic między ludźmi, posiadanych przez nich rozmaitych zdolności, które mogliby realizować, oferowanie wszystkim standardowego zestawu dóbr pierwotnych nie oznacza, że wszyscy zaczną urzeczywistniać swe zdolności, ponieważ osoby starsze albo cierpiące na pewne choroby mogą nie skorzystać z dostarczonych im dóbr, potrzebują bowiem dóbr swoistych, by prowadzić zadowalające życie (Mikłaszewska 2014: 27-28). Wyjaśniając zjawisko biedy, a tym samym wykluczenia społecznego, Sen zauważa, że pewne grupy ludzi tracą swe dotychczasowe uprawnienia i siłę nabywczą nie z tytułu braku dóbr, ale w związku z niesprawiedliwą dystrybucją i ich nieadekwatnością, co sprawia, że nie stwarzają one jednostkom okazji do wyjścia poza dany poziom egzystencji (Sen 2002).

Analizując sumarycznie pojawiające się dyskursy socjologiczne dotyczące wykluczenia w perspektywie genetycznej, można przyjąć, że najwcześniej pojawiła się teoria nierówności społecznych i teoria podklasy - underclass (Frieske 1999; Kaźmierczak, Łuczyńska 1998; Kowalak 1998). Proces marginalizacji lub deprywacji społecznej łączy się ze zjawiskami społecznej ekskluzji (wyłączenia) i sytuacją „wycofania się, czy też wytrącania ludzi z rozmaitych wymiarów porządku społecznego..." (Frieske, Sikorska 1994). Stan ten traktuje się jako brak - lub niepełną partycypację - w życiu społecznym, który stoi w sprzeczności z modelem społeczeństwa obywatelskiego, a jednym $\mathrm{z}$ jego zasadniczych założeń jest powszechne uczestnictwo (Kaźmierczak, Łuczyńska 1998: 29).

Współcześnie w zjawisku wykluczenia społecznego w sposób szczególny akcentuje się jego wymiar społeczno-strukturalny, systemowy czy też sytuacyjny. W podejściu tym przesuwa się środek ciężkości z aspektu indywidualnego przyczyn wykluczenia społecznego (podejścia psychospołeczne i behawioralne) ku społecznym aspektom jego uwarunkowań, w kierunku postrzegania tego procesu przez pryzmat społeczeństwa, które wyklucza i marginalizuje, które nie sprawdza się w zapewnieniu jednostkom i zbiorowościom pełnego uczestniczenia w życiu społecznym (por. Tarkowska 2005a: 20). Takie postrzeganie procesu wyłączania ma szczególny wpływ na kształtowanie nowej polityki społecznej i działań w zakresie pracy socjalnej - mają mu zapobiegać bądź go przynajmniej lagodzić.

Odpowiedzią na procesy wykluczenia społecznego (ekskluzji) jest proces włączania (inkluzji), który stanowi element międzynarodowej polityki spójności i jest rozpatrywany w kontekście interdyscyplinarnym oraz multiprofesjonalnym. Zakłada się, że wykraczając ponad dostarczenie potrzebującym zasobów materialnych, polega on na zwiększeniu dostępu i poprawie funkcjonowania usług socjalnych oraz edukacyjnych w środowisku życia jednostki wykluczonej, w kierunku pobudzania do aktywności społecznej i obywatelskiej na rzecz budowania bardziej spójnej i harmonijnej „struktury społecznej dla wszystkich" (por. Szarfenberg 2004: 8).

$\mathrm{W}$ społeczeństwie nowoczesnym, promującym równość szans, prawo do samookreślenia, odpowiedzialności jednostki za własny los, procesy stygmatyzacji i marginalizacji są traktowane jako bezprawie i podejmuje się wiele działań, by asymilować i integrować jednostki oraz grupy dotknięte wykluczeniem. Pojawiają się więc różne strategie przeciwdziałania ekskluzji, które nie zawsze przynoszą oczekiwane rezultaty, 
więc powinny zostać poddane krytycznej refleksji. Taką refleksję nad pejoratywnymi aspektami procesu asymilacji podejmuje Zygmunt Bauman.

Program asymilacji obiecuje dom otwarty i namawia tych, którzy jak dotąd nie czują się u siebie w domu, aby byli kowalami własnego losu, zapewniając ich zarazem, że tylko od rzetelności ich wysiłków zależy ich los. Głosi przysługujące każdemu prawo do ubiegania się i osiągania najbardziej pożądanych wartości i obiecuje ich powszechną osiągalność (Bauman 1995: 102).

Według Z. Baumana program kulturowego ujednolicania czy też integracji w swym liberalnym wydaniu posiada wiele wewnętrznych sprzeczności. Ujawnia z jednej strony wyższość danej kultury nad inną oraz szlachetność i dobrą wolę panujących; z drugiej daje możliwość obciążania „upośledzonych” winą za los, z jakiego wydobyć się nie umieją lub nie chcą. Autor ten zauważa, że liberalne podejście do integracji zdecydowanie obciąża samych wykluczanych, ponieważ „...) Jeśli zaś nie poddadzą się procesom inkluzji, przyznają się do winy i niezaradności, mogą powrócić do grupy tych wykluczanych" (Bauman 1995: 103). Biorąc pod rozwagę analizę zjawiska społecznej koherencji dokonaną przez Z. Baumana, zauważamy, że proces społecznego włączania musi być czymś więcej niż procesem integracji społeczno-kulturowej, musi burzyć stereotypowe znaczenie uczestnictwa społecznego przez akceptację odmienności oraz wieloznaczności indywidualnej i zbiorowej egzystencji we współczesnym świecie, a także ich wzajemnych powiązań.

Można zatem przyjąć, że proces społecznej inkluzji to taka praktyka, która jest świadoma hermeneutycznej wieloznaczności norm i wartości oraz możliwości alternatywnych działań prowadzących do włączania. W kontekście inkluzji to praca socjalna jako dziedzina działalności profesjonalnej ma być odpowiedzialna za wyrównywanie szans osób wykluczanych i ich społeczną integrację.

\section{Praca socjalna wobec społecznego wykluczenia i procesu inkluzji}

Na gruncie pracy socjalnej odnajdujemy teorie, które stanowią ramy profesjonalnego działania w stosunku do osób i grup wykluczonych społecznie. Najszerzej aplikowanymi koncepcjami na tym polu są teorie antydyskryminacyjne i emancypacyjne (emancipatory approaches) (Dominelli 1998; Szmagalski 2003). Mają one szczególne znaczenie dla wyjaśniania procesów ekskluzji oraz opisywania tych elementów struktury życia społecznego, które determinują praktykę działań socjalnych przeciw wykluczeniu, a wśród nich:

- istnienie obiektywnych zróżnicowań warunków życia społeczeństw czy społeczności, które powodują, że niektóre osoby i grupy bardziej niż inne są narażone na wykluczenie społeczne;

- istnienie barier formalnych (czasowych, przestrzennych) między instytucjami socjalnymi, wychowawczymi i innymi a samymi świadczeniobiorcami (ograniczony lub utrudniony dostęp do tych instytucji), które przyczyniają się do procesów wykluczania społecznego lub te procesy pogłębiają; 
- istnienie nowych zależności w ramach systemu edukacji i pomocy społecznej, które kształtują warunki współczesnego życia osób i/z grup ryzyka (między innymi zależność zakresu wsparcia od dominującego modelu pomocy społecznej, od możliwości instytucjonalnych i profesjonalnych oferowanych usług $\mathrm{w}$ danych społecznościach lokalnych, a także komercjalizacja niektórych usług edukacyjnych i socjalnych);

- profesjonaliści społeczni jako reprezentanci instytucji socjalnych i edukacyjnych odgrywają znaczącą rolę w kwalifikowaniu indywidualnych przypadków ludzi wykluczanych (poprzez między innymi diagnozę socjalno-wychowawczą kształtują ludzkie biografie, a tym samym pośrednio ukierunkowują procesy funkcjonowania społecznego i uczestnictwa ludzi w życiu danych społeczności);

- indywidualne biografie ludzi z grup ryzyka, z grup objętych wsparciem, zwykle nie korespondują z żadną ofertą pojedynczej instytucji, gdyż są uwikłane w wiele kontekstów i problemów życia społecznego, toteż wymagają rozwiązań systemowych, czego niezbędnym warunkiem jest daleko idąca współpraca między instytucjami zaangażowanymi w proces włączania społecznego (por. Kantowicz 2008: 153).

Ponadto sama praktyka pracy socjalnej pokazuje, że ludzie z grup ryzyka (dzieci i młodzież niedostosowana społecznie, uzależnieni, ubodzy, niepełnosprawni, bezdomni i inni) ulegają wykluczeniu między innymi przez odrzucenie (częściowe lub całkowite) norm funkcjonowania w danej społeczności. Zwykle osoby te kierowane są do „specjalnych" instytucji, które mają pomóc w ponownym włączeniu do życia w społeczeństwie, niemniej jednak samo umieszczenie $\mathrm{w}$ danej instytucji jest segregacją. Profesjonalne wysiłki inkluzyjne powinny polegać na przywracaniu zdolności rozwoju i społecznego funkcjonowania przez indywidualnie pojętą kompensację, resocjalizację, reintegrację. „Wykluczony”, by sprostać warunkom inkluzji, powinien zaakceptować przyjęte przez większość wartości i nałożone role. Jeśli tego nie czyni, dalej pozostaje „obcym”. Proces włączania jest więc procesem nabywania nowych umiejętności i kompetencji prawidłowego funkcjonowania w społeczeństwie.

W świetle powyższych rozważań największym wyzwaniem dla profesjonalistów społecznych jest rewizja myślenia o procesach społecznej inkluzji oraz refleksja nad możliwościami i barierami działań integrujących. W obliczu wzrastającej liczby osób określanych jako wykluczani/wykluczeni społecznie: bezdomnych, upośledzonych, niepełnosprawnych, psychicznie chorych, uzależnionych, ubogich, bezrobotnych, migrantów, czyli „Tych Innych”, którzy stają się ważnymi świadczeniobiorcami wyspecjalizowanych instytucji socjalno-wychowawczych, ważnym zadaniem jest kształtowanie nowej świadomości i odpowiedzialności społecznej, a także to, co określamy mianem budowania społeczeństwa obywatelskiego. 


\title{
Międzynarodowa praca socjalna a procesy inkluzji
}

Na gruncie międzynarodowym odnajdujemy wiele dokumentów wypierających pojęcie „wykluczania społecznego” na rzecz procesów odwrotnych, takich jak: „włączanie”, „inkluzja”, „integracja”, które z kolei stają się wytyczną dla tworzenia międzynarodowej oraz europejskiej polityki spójności (social cohesion).

W kontekście pracy socjalnej na szerzenie się nierówności, dyskryminacji i wykluczenia mają wpływ bariery socjoekonomiczne, kulturowe o charakterze strukturalnym. Toteż w międzynarodowej pracy socjalnej podkreśla się znaczenie rozwoju świadomości krytycznej poprzez refleksję nad strukturalnymi źródłami ucisku i przywilejów społecznych na podstawie takich kryteriów, jak: rasa, klasa, język, religia, płeć, niepełnosprawność, orientacja seksualna. Jednym z priorytetowych zadań jest więc rozwijanie strategii akcji mających na celu zlikwidowanie strukturalnych i osobistych barier. Realizacja tych zadań jest warunkiem emancypacyjnej i integracyjnej praktyki, a jej celami są: wyzwolenie i upełnomocnienie ludzi (Kantowicz 2015: 255).

Najnowsza definicja pracy socjalnej przyjęta przez społeczność międzynarodową przyjmuje, że:

\begin{abstract}
Praca socjalna to zarówno praktyczny zawód, jak i dyscyplina akademicka, która napędza zmiany i rozwój społeczeństwa, spójność społeczną oraz działa jako narzędzie upełnomocniające i wyzwalające ludzi. Zasady sprawiedliwości społecznej, praw człowieka wspólnej odpowiedzialności i poszanowania dla różnorodności są kluczowymi elementami pracy socjalnej. Opierając się na teorii pracy socjalnej, naukach społecznych, humanistycznych i wiedzy rodzimej, praca socjalna angażuje ludzi i struktury do stawienia czoła największym wyzwaniom życia i działania ku jego poprawie (http://ifsw.org/ policies/indigenous-peoples; dostęp: 14.12.2018).
\end{abstract}

Przyjmuje się, że we współczesnej pracy socjalnej działania podejmowane przez profesjonalistów traktuje się nie jako interwencję w "nienormalnie” przebiegający proces socjalizacji jednostek i grup ulegających marginalizacji społecznej oraz objętych wsparciem i pomocą, ale jako proces ukierunkowany na pomoc w rozwoju jednostek, grup i społeczności, zorientowany na poprawianie relacji interpersonalnych, na aktywizowanie i mobilizowanie do pozytywnych zmian oraz podnoszenia jakości własnego życia. Normatywne funkcje pracy socjalnej definiują też działania w jej zakresie, a oparte są przede wszystkim na zasadach ochrony praw człowieka, sprawiedliwości społecznej, pomocniczości. Zasady te w sposób istotny pozwalają określać wartości preferowane w działaniach profesjonalnych i strategiach organizacji pomocy na rzecz wykluczanych lub już wykluczonych z życia społecznego.

Agendą na rzecz międzynarodowej pracy socjalnej przeciw wykluczeniu stała się przyjęta w marcu 2012 roku przez Międzynarodową Federację Pracowników Socjalnych (International Federation of Social Workers, IFSSW), Międzynarodowe Stowarzyszenie Szkół Pracy Socjalnej (International Association of Schools of Social Work, IASSW) i Międzynarodową Radę Pomocy Społecznej (International Council of Social Welfare) 
„Globalna Agenda na rzecz Pracy Socjalnej”, w której uznano, że przeszłe i obecne łady polityczne, ekonomiczne, kulturowe i społeczne, kształtowane w określonych kontekstach, skutkują nierównymi konsekwencjami dla globalnych, narodowych oraz lokalnych społeczności i wywierają negatywne wpływy na życie ludzi (Szmagalski 2014).

$\mathrm{W}$ preambule agendy wskazano na istnienie w społeczeństwach wielu dysproporcji i nierówności, które determinują procesy wykluczenia:

- pełny zakres praw człowieka jest dostępny tylko dla mniejszości światowej populacji;

- niesprawiedliwe i źle uregulowane systemy ekonomiczne, napędzane przez nieodpowiedzialne siły rynku, razem z niezgodnością z międzynarodowymi standardami warunków pracy i brakiem społecznej odpowiedzialności korporacji niszczą zdrowie i samopoczucie ludzi oraz społeczności, powodując biedę i narastające nierówności;

- kulturowa różnorodność i prawo do wyrażania siebie ułatwiają bardziej satysfakcjonującą intelektualną, emocjonalną, moralną i duchową egzystencję, ale prawa te są $\mathrm{w}$ niebezpieczeństwie $\mathrm{z}$ powodu tych aspektów globalizacji, które standaryzują i marginalizują ludzi, ze szczególnie szkodliwymi konsekwencjami dla rdzennej ludności;

- ludzie żyją w społecznościach i dobrze się rozwijają w kontekście wspierających relacji, ale zostały one naruszone przez dominujące siły ekonomiczne, polityczne i społeczne;

- zdrowie ludzi i ich dobrostan cierpią z powodu nierówności i niezrównoważonych środowisk wynikających ze zmian klimatu, zanieczyszczeń, wojen, klęsk żywiołowych i przemocy, wobec których międzynarodowe reakcje są nieadekwatne.

Organizacje międzynarodowe działające w sferze pracy socjalnej opowiadają się za nowym porządkiem świata, walką o poszanowanie praw człowieka i jego godności oraz zmianą struktury relacji międzyludzkich. Jednocześnie zobowiązano się do wspierania, inspirowania i promowania globalnych inicjatyw nastawionych na osiąganie równości socjalnej i ekonomicznej, wspomagania, oddziaływania i wzmacniania struktur oraz systemów, które przeciwstawiają się przypadkom opresji i nierówności, a także do podjęcia działań na rzecz wspólnej pracy z ludźmi, którzy korzystają z systemów wsparcia i podzielają cele i aspiracje do tworzenia bardziej sprawiedliwego i uczciwego świata.

Dla osiągnięcia celów współpracy międzynarodowej w dziedzinie sprawiedliwości społecznej, równości i koherencji organizacje ustaliły następujące priorytety:

1. Promowanie społecznych i ekonomicznych równości.

2. Promowanie godności i wartości człowieka.

3. Pracę na rzecz zrównoważonego środowiska życia człowieka.

4. Wzmacnianie uznania dla ważności stosunków międzyludzkich.

Zobowiązania te są zgodne ze stanowiskami zawartymi w definicji pracy socjalnej $\mathrm{i}$ jej zasadami etycznymi. Zgodnie $\mathrm{z}$ agendą organizacje związane $\mathrm{z}$ pracą socjalną mają dążyć do globalnego zastosowania międzynarodowych konwencji i innych instrumentów 
socjalnych, ekonomicznych, kulturalnych i politycznych praw dla wszystkich ludzi, w tym praw dzieci, ludzi starszych, kobiet, osób niepełnosprawnych, rdzennej ludności, i do zatrzymania dyskryminacji z powodu rasy i orientacji seksualnej (Szmagalski 2014: 2). Organizacje zobowiązały się też pracować $\mathrm{z}$ różnymi partnerami na rzecz przeciwstawiania się państwowej przemocy w reakcjach na działania ludzi występujących w obronie swoich praw oraz bronić praw ludzi do przemieszczania się między państwami i w samym państwie, a także walczyć o prawa zalegalizowanych i niezalegalizowanych migrantów do świadczeń socjalnych, plus wspierać działania dążące do redukcji i eliminacji handlu ludźmi.

Ważnym wydarzeniem związanym z wdrażaniem międzynarodowej polityki spójności było spotkanie szefów państw, które odbyło się 30 maja 2013 roku na forum ONZ tak zwany Panel Wysokiego Szczebla w Sprawie Agendy Rozwoju po Roku 2015 (High Level Panel on the Post-2015 Development Agenda). W raporcie pod tytułem „Nowe Globalne Partnerstwo: Wyeliminowanie ubóstwa i transformacja gospodarek zgodnie ze zrównoważonym rozwojem", będącym rezultatem spotkania, przedstawiono plan eliminacji skrajnego ubóstwa do 2030 roku i spełnienia obietnicy związanej z osiągnięciem zrównoważonego rozwoju oraz globalnego partnerstwa (www.unic.un.org.pl/ aktualnosci.php? wid=34\&news=2466; dostęp: 14.12.2018).

Ta nowa, międzynarodowa „Agenda Rozwoju po 2015 roku” jeszcze wyraźniej podkreśliła potrzebę wyeliminowania skrajnego ubóstwa do 2030 roku oraz budowania nowego globalnego partnerstwa poprzez takie przekształcanie gospodarek narodowych, aby stworzyć miejsca pracy i zapewnić inkluzyjny rozwój. Warunkiem zrównoważonego rozwoju jest budowanie pokoju i partnerstwa na świecie oraz skuteczne, otwarte i odpowiedzialne tworzenie instytucji dostępnych dla wszystkich (www.post2015hlp. org; dostęp: 06.08.2018).

\section{Międzynarodowa praca socjalna jako obszar działań inkluzyjnych}

Można umownie przyjąć, że umiędzynarodowienie pracy socjalnej dokonało się za pośrednictwem Konferencji Pracy Socjalnej w Paryżu w 1928 roku, na której przedstawiciele wielu krajów - badacze problemów społecznych i nauczyciele szkół pracy socjalnej - zainicjowali utworzenie międzynarodowej organizacji - IASSW. Stowarzyszenie to zapoczątkowało rozwój współpracy międzynarodowej w zakresie badań i kształcenia do pracy socjalnej, promowania wspólnych standardów edukacji akademickiej, wymiany doświadczeń w sferze badawczo-dydaktycznej, wymiany doświadczeń w zakresie tak zwanych dobrych praktyk oraz internacjonalizacji, a także zarządzania rozwojem instytucji działających w obszarze pracy socjalnej (por. Kantowicz 2017: 465-467).

Za twórcę pojęcia „międzynarodowa praca socjalna” i wyjaśnienia jej istoty uważa się George’a L. Warrena, który był znawcą problemów migracji (Szmagalski 2008: 346). W rozwoju koncepcji międzynarodowej pracy socjalnej ukształtowały się trzy zakresy jej rozumienia: 
1. Poznawanie i wykorzystywanie metod pracy socjalnej w różnych krajach.

2. Działania narodowe i międzynarodowe związane z pomocą innym krajom w sytuacji niedostatku ekonomicznego, klęsk żywiołowych i skutków wojen.

3. Działania narodowe i międzynarodowe na rzecz wspierania migrantów i uchodźców w rozwiązywaniu ich problemów socjalnych i życiowych.

Ponadto współcześnie w tych trzech zakresach odnajdujemy wspólne zamiary społeczności międzynarodowej związane z przeciwdziałaniem dyskryminacji, opresyjnemu traktowaniu słabszych i wykluczeniu społecznemu (por. Szmagalski 2008: 346).

Aktualnie realizowane są także ponadnarodowe działania na rzecz inkluzji migrantów na szczeblu ONZ i UE, które obejmują między innymi tworzenie sieci współpracy między podmiotami zajmującymi się uchodźcami w państwach członkowskich UE, tworzenie kampanii na rzecz zwiększania świadomości społecznej, rozpowszechnianie dobrych praktyk na rzecz inkluzji, rozwój sieci łączących organizacje pozarządowe, których celem jest ułatwienie wymiany doświadczeń. Działania te są pośrednio powiązane $\mathrm{z}$ transnacjonalizmem jako koncepcją integracji, ale także jako konkretnym układem zależności między „aktorami”, operującymi w ONZ czy Unii Europejskiej na poziomie ponadnarodowym (Ruszkowski 2010: 17-18). Transnacjonalizm to nie tylko innowacyjny mechanizm współpracy międzynarodowej, lecz także sposób ponadnarodowego zarządzania partycypujących w tych procesach instytucji wspólnotowych (Ruszkowski 2010: 19).

Wśród ostatnio podejmowanych inicjatyw ponadnarodowych, dotyczących rozwiązywania kwestii migracji, jest przyjęte 13 lipca 2018 roku specjalne Porozumienie Organizacji Narodów Zjednoczonych Global compact for safe, orderly and regular migration na rzecz bezpiecznej, uporządkowanej i legalnej migracji, które jest pierwszą na taką skalę odpowiedzią na jedno z największych wyzwań XXI wieku i pierwszym krokiem w stronę wspólnej polityki migracyjnej. Przyjmuje się, że kryzys migracyjny z 2015 roku był największym od czasów drugiej wojny światowej. W roku 2017 liczba migrantów sięgnęła 258 milionów, czyli 3,4 procenta populacji globu. Największą grupę stanowiły osoby urodzone w Azji (106 milionów), ale drugą w kolejności - migranci urodzeni w Europie (61 milionów). Treść porozumienia zatwierdzono i zostało ono przyjęte w grudniu 2018 roku podczas konferencji w Marrakeszu (https://oko.press/pis-wpuszcza-najwiecej-migrantow-porozumienie-onz-odrzuca-bo-migrantow/; dostęp: 20.01.2019).

W porozumieniu określono 23 cele, wśród nich: minimalizację czynników, które zmuszają ludzi do opuszczenia kraju pochodzenia, zwiększenie dostępności i różnorodności dróg legalnej migracji, ratowanie życia i poszukiwanie zaginionych migrantów oraz walka $\mathrm{z}$ handlem ludźmi, zintegrowane, bezpieczne i skoordynowane zarządzanie granicami, współpraca w ułatwianiu bezpiecznego i godnego powrotu oraz reintegracji migrantów w kraju pochodzenia, eliminacja wszelkich form dyskryminacji i wzmacnianie opartego na faktach dyskursu o migracji, zapewnienie dostępu do podstawowych usług dla migrantów (niezależnie od statusu), praca na rzecz pełniej integracji migrantów w społecznościach przyjmujących. Warto zaznaczyć, że porozumienie jest jedynie 
deklaracją i do niczego sygnatariuszy państw ONZ nie zobowiązuje, a mimo tego rząd polski przyją już decyzję o niepodpisaniu porozumienia w dniu 20 listopada 2018 roku (https://oko.press/pis-wpuszcza-najwiecej-migrantow-porozumienie-onz-odrzuca-bo-migrantow/; dostęp: 20.01.2019).

W związku ze złożonymi procesami globalizacji, powszechnej migracji, swobody przepływu ludności oraz swobody konsumpcji, a także wielokulturowości, fragmentaryzacji tożsamości narodowych, polaryzacji społecznej, pojawiania się nowych związków społeczno-kulturowych i nowych tożsamości klasowych na gruncie międzynarodowej pracy socjalnej toczą się nowe dyskursy. Korespondująca z tymi procesami jest na przykład analiza zjawiska indygenizacji, podejmowana przez australijską badaczkę społeczną Mel Grey (2005). Refleksja nad aplikowanymi strategiami, programami czy profesjonalnymi działaniami w obszarze międzynarodowej pracy socjalnej jest też przedmiotem rozważań innych badaczy - Davida Coxa, Monohara Pawara, Lynne M. Healy (Cox, Pawar 2006; Healy 2008).

\section{Uwagi końcowe}

Wzrastająca liczba osób określanych jako wykluczani społecznie: biedni (we współczesnej Europie żyje około 64 milionów osób uznanych za ubogie), bezdomni, upośledzeni, niepełnosprawni, uzależnieni, bezrobotni, dzieci i młodzież z grup ryzyka oraz migranci powoduje, że stają się oni ważnymi świadczeniobiorcami wyspecjalizowanych instytucji socjalnych. W obliczu tego wyzwania, oprócz zmiany polityki społeczno-gospodarczej wobec osób i grup podlegających procesom wykluczania, ważnym zadaniem jest kształtowanie nowej świadomości społecznej i odpowiedzialności.

Odpowiedzialność za los wykluczanych powinna leżeć nie tylko w gestii polityków społecznych i praktyków działań inkluzyjnych - musi wynikać z odpowiedzialności ogólnospołecznej - z jednej strony za procesy segregacyjne, $z$ drugiej za działania integracyjne, a także ochronę praw wykluczanych oraz ich możliwość „, mówienia własnym głosem” i współtworzenia „własnych biografii”.

Prawie stuletnie doświadczenia współpracy i wymiany doświadczeń w zakresie międzynarodowej pracy socjalnej wskazują, że jest to nie tylko warunek rozwoju teorii i praktyki pracy socjalnej przeciw wykluczeniu, lecz także element realizacji polityki spójności i różnych działań inkluzyjnych.

Praca socjalna zarówno w kontekście globalnym, jak i narodowym skoncentrowana na inkluzji powinna cechować się krytycznym i refleksyjnym dystansem do realizowanych strategii i programów pomocy, zachowując wrażliwość na specyfikę potrzeb jednostek i grup wykluczanych. Szczególnie międzynarodowa praca socjalna nie może być tylko praktyką interwencyjną, ale powinna być kompleksowo realizowaną działalnością aktywizująco-wspierającą, która jest otwarta na ochronę różnych praw oraz niekonwencjonalne rozwiązania, a także powinna rozwijać nową wiedzę o procesach wykluczania czy też możliwych strategiach wspierania osób wykluczanych. 


\section{Bibliografia}

Bauman Z. (1995). Wieloznaczność nowoczesna - nowoczesność wieloznaczna. PWN, Warszawa.

Cox D., Pawar M. (2006). International Social Work. Issues, Strategies and Programs. Sage Publications, London-New Delhi.

Davies M. (red.) (2003). The Blackwell Encyclopaedia of Social Work. Blackwell Publishing, Oxford.

Domański H. (2004). Struktura społeczna. Wydawnictwo Naukowe Scholar, Warszawa.

Dominelli L. (1998). Anti-opresive practice in context, w: R. Adams, L. Dominelli, M. Payne (red.), Social Work. Themes, Issues and Critical Debate. Palgrave, London: 3-22.

Frieske K.W. (1999). Marginalizacja społeczna w małych społecznościach lokalnych. „Polityka Społeczna”, 11/12: 5-16.

Frieske K.W. (red.) (2004). Utopie inkluzji. Sukcesy i porażki programów reintegracji społecznej. IPSS, Warszawa.

Frieske K.W., Sikorska J. (1994). Marginalizacja-partycypacja: pobocza oficjalnego porządku społecznego, w: K. Frieske, W. Morawski (red.), W biegu czy zawieszeniu. Ludzie i instytucje $w$ procesie zmian. IS UW, Warszawa.

Grey M. (2005). Dilemmas of International Social Work: Paradoxical processes in indigenization, universalism and imperialism. „International Journal of Social Welfare”, 14 (3).

Healy L.M. (2008). International Social Work - Professional Actions in an Idependent World. Oxford University Press, New York.

http://ifsw.org/policies/indigenous-peoples (dostęp: 21.11.2018).

https://oko.press/pis-wpuszcza-najwiecej-migrantow-porozumienie-onz-odrzuca-bo-migrantow/ (dostęp: 24.11.2018).

Kantowicz E. (2008). Teorie pracy socjalnej wobec procesu wykluczenia społecznego, w: K. Marzec-Holka, A. Rutkowska, M. Joachimowska (red.), Praca socjalna i polityka społeczna - obszary współdziałania wobec wykluczenia społecznego. Wydawnictwo UKW, Bydgoszcz: 289-297.

Kantowicz E. (2015). Normatywne i teoretyczno-praktyczne wymiary współczesnej pracy socjalnej - refleksje na kanwie nowej definicji pracy socjalnej, w: A. Kieszkowska (red.), Prawda, dobro, piękno. Wymiar filozoficzno-prawny i socjopedagogiczny. Difin, Warszawa: 252-260.

Kantowicz E. (2017). Rola wspótpracy międzynarodowej w kreowaniu przestrzeni badań komparatystycznych i kształcenia do pracy socjalnej, w: B. Kromolicka, A. Jarzębińska (red.), O (wyzwaniach) współczesnej pracy socjalnej. Nowe problemy - zmiana - transgresja. Wolumina pl. Daniel Krzanowski, Szczecin: 465-476.

Kawula S. (1997). Spirala życzliwości: od wsparcia do samorozwoju, w: E. Kantowicz (red.), Wsparcie społeczne w różnych układach ludzkiego życia. Wydawnictwo Glob, Olsztyn: 11-17. Kowalak T. (1998). Marginalność i marginalizacja społeczna. Wydawnictwo ELIPSA, Warszawa. Kaźmierczak T., Łuczyńska M. (1998). Wprowadzenie do pomocy społecznej. BPS, Katowice.

Mikłaszewska J. (2014). Teorie sprawiedliwości społecznej: Amartya Sen i Martha Nussbaum. „Prakseologia”, 156: 25-46.

Payne M. (2003). Social theory and social work, w: M. Davies (red.), The Blackwell Encyclopaedia of Social Work. The Blackwell Publishing, Oxford: 330-332. 
Ruszkowski J. (2010). Ponadnarodowość w systemie politycznym UE. Oficyna Wydawnicza „Impuls”, Warszawa.

Sałustowicz P. (2003). Social exclusion and globalization - A new theoretical approach for social work, w: Ch. Labonte-Roset, E. Marynowicz-Hetka, J. Szmagalski (red.), Social Work Education and Practice in Today's Europe. Challenges and the Diversity of Responses. Wydawnictwo Śląsk, Katowice.

Sen A. (2002). Rozwój i wolność, tłum. J. Łoziński. Zysk i Ska, Poznań.

Szacka B. (2003). Wprowadzenie do socjologii. Oficyna Naukowa s.c., Warszawa.

Szarfenberg R. (2004). Marginalizacja i wykluczenia społeczne. Wykład monograficzny 2004/2005; www.ips.uw.edu.pl/szarf/wykluczenie (dostęp: 12.10.2017).

Szarfenberg R. (2017). www.ips.uw.edu.pl/rszarf./wykluczenie/(dostęp: 10.06.2018).

Szmagalski J. (2003). W europejskim kręgu inspiracji teoretycznych współczesnej pracy socjalnej, w: E. Kantowicz, A. Olubiński (red.), Działanie społeczne w pracy socjalnej na progu XXI wieku. Wydawnictwo Akapit, Toruń: 63-72.

Szmagalski J. (2008). Międzynarodowa praca socjalna wobec problemów pomocy migrantom i uchodźcom, w: D. Lalak (red.), Dom i ojczyzna. Dylematy wielokulturowości. Międzynarodowe Centrum Adaptacji Narodowej, Warszawa: 345-357.

Szmagalski J. (red.) (2014). Globana Agenda - zaangażowania i działania dla pracy socjalnej i rozwoju społecznego. Tekst przetłumaczony z oryginału udostępnianego na portalu Council of Social Work Education; http://www.cswe.org/File.aspx?id=60880/ (dostęp: 23.04.2018).

Tarkowska E. (2005a). Kategoria wykluczenia społecznego a polskie realia, w: M. Orłowska (red.), Skazani na wykluczenie. Wydawnictwo APS, Warszawa.

Tarkowska E. (2005b). Bieda w Polsce w świetle badań jakościowych - próba podsumowania, w: S. Golinowska, E. Tarkowska, I. Topińska (red.), Ubóstwo i wykluczenie społeczne. Badania, metody, wyniki. IPiSS, Warszawa.

Winiarski M. (1999). Integracja społeczna, w: D. Lalak, T. Pilch (red.), Elementarne pojęcia pedagogiki społecznej i pracy socjalnej. Wydawnictwo Żak, Warszawa: 108-110.

www.post2015hlp.org (dostęp: 6.08.2018).

www.unic.un.org.pl/aktualnosci.php?wid=34\&news=2466 (dostęp: 6.08.2018). 